\title{
"I Cannot See the Day They Will Make a New Chief": Historically Created Uncertainties about Sacred, Kingly, Populist and Secular Values in Lau, Fiji
}

\author{
Simonne Pauwels SHS, CNRS
}

\begin{abstract}
In Fiji, Lauan paramount chiefs have always been sacred - kingly and populist - but through time they also became secular chiefs - representatives of the colonial power and later politicians and statesmen. For some, the status of sacred chief had to consolidate their secular status, for others, their status of secular chief received the illusion of sacredness through title manipulation. The latter were even subject to territorial expansion. Chiefs themselves, whether secular, sacred or both, maintained a confusion between sacred and secular rights and duties. Recent fieldwork reveals grumbling and frustration among the Lauans, as these facts created a multitude of points of view they increasingly expressed because of the absence of a paramount chief for 13 years. This made them less respectful toward the title and resulted in the feeling of being able to do without a paramount chief. At the same time, however, the contradictory idea that a chief is the only person who can restore the value of respect and order into the community is still vivid.
\end{abstract}

Keywords: Fiji, Lau Province, mana, chiefs, respect

Résumé : Aux Îles Fidji, les chefs suprêmes Lauans ont toujours été des chefs sacrés - royaux et populistes -, mais avec le temps, ils sont aussi devenus des chefs séculiers -des représentants du pouvoir colonial et, plus tard, des hommes politiques et des hommes d'État. Pour les uns, le statut de chef sacré devait consolider leur statut séculier, pour les autres, la manipulation des titres devait conférer une apparence de sacré à leur statut de chef séculier - les titres ayant même fait l'objet d'une expansion territoriale. Les chefs eux-mêmes, qu'ils soient séculiers, sacrés ou les deux, ont entretenu une confusion entre droits et devoirs sacrés et séculiers. Une récente enquête de terrain révèle l'ampleur des frustrations et des récriminations chez les Lauans. En effet, ces événements ont engendré une multitude de points de vue qui s'expriment de plus en plus ouvertement depuis treize ans du fait de l'absence de chef suprême. Dans ce contexte, les Lauans se montrent moins respectueux envers le titre et ont le sentiment de pouvoir se passer d'un chef suprême. Or, au même moment, l'idée que seul un chef peut restaurer les valeurs de respect et d'ordre dans la communauté demeure bien vivante.

Mots-clés : Fiji, province de Lau, mana, chefs, respect.

Anthropologica 61 (2019) 227-239
A rchival $^{1}$ and historical, ${ }^{2}$ as well as ethnographic, ${ }^{3}$ Aresearch allows me to show that the definition of the ideal chief by Marcus (1989), inspired by Howard's analysis in Rotuma (Howard 1985), is still relevant today in the chiefdom of Lau in Fiji in spite of a turbulent history (Christianisation, wars, colonisation), a conflicting understanding of land "ownership," various manipulations of titles, and the vacancy of the title for more than a decade. Remarkably, as revealed by ethnography, it is through the absence of a chief and the questioning of the need for one that nonchiefly members of the chiefdom, living on Lakeba Island, the seat of the paramount chief of the chiefdom, were able to formulate a description of the ideal chief.

Two qualities of chieftainship are combined in different ways in different Polynesian societies. One sees the chief as a sacred being, socially distant and not accountable to ordinary standards of behaviour. The other considers him an exemplary being, embodying the ideals of personhood, approachable, and accountable as an ordinary person (Marcus 1989, 176-178). The first is summarised as the kingly side of the chief and the second as the populist side. Neither of them is exclusive; they mostly coexist, even if the populist side seems to get the upper hand. This coexistence is a source of tension, which is particularly manifest in a context of great uncertainty about the kind of leadership to choose, as currently in Lakeba. This article uncovers the roots of this uncertainty through an analysis of local history, which was influenced, among other factors, by the fact that two distinguished statesmen were closely linked to the chiefdom. Lakeba Island is the homeland of Ratu Kamisese Mara (1920-2004), who was not only its paramount chief but also the founding father of the modern nation of Fiji after the colony won independence from Britain in 1970. He was its first prime minister until $1992^{4}$ and subsequently president until the coup of 2000 . His carrier was significantly the work of another Fijian statesman, Ratu Sukuna, his mentor and second cousin 
once removed. The latter was the most important Fijian statesman during the colonial period as the architect of the Native Lands Trust Board (NLTB) to administer native land and as Secretary for Fijian Affairs.

My fieldwork on the island started at the end of 2005, nearly two years after Ratu Kamisese Mara's death. Until this day he was the last paramount chief of the chiefdom of Lau, whose titles, as will be discussed in this article, were Na Gone Turaga na Tui Lau, Tui Nayau ka Sau ni Vanua ko Lau. My interrogation about his succession is still ongoing today. During each of my stays in Lakeba, along with other subjects of interest (Pauwels 2015a; 2015b), I asked about the status of the issue, but after a few years, I noticed some reluctance to answer my inquiries, for reasons that will become clear in this article. The most important, the unwillingness of Mara's eldest son to accept the title, is fairly common knowledge. The reasons given are numerous and depend on the interlocutor. They range from "the right people did not ask him" to "he does not want to live in a village" or "his health does not allow him." Nobody belonging to the chiefly group would directly disclose his or her thoughts. I was told that the topic was private to the chiefly clan, which, even if divided into factions, showed solidarity in its discretion. As an anthropologist, I decided to respect this need for tact.

However, having a number of acquaintances in every village on the island, I decided in 2015 to take advantage of a visit around the island for the purpose of investigating the relationship between "clans," mataqali, and certain fish species and related knowledge to question the relevance of installing a chief after a decade of vacancy as well. Indirectly, this query also clarified their ideas about what would make an ideal chief. The discussions on the subject were ticklish and started only after the conversations on fishes and clans. All my interlocutors asked me not to reveal their identities when writing about the topic. However, disagreement within the audience turned out not to be a problem. So one wonder which listeners would not have been welcome, not even as future readers? Knowing that all my interlocutors are commoners, ${ }^{5}$ the answer is easy and the reasons will become clear throughout this article. Most of my interlocutors were men, because the public purpose of my visit to the villages concerned clan knowledge. Sometimes women were present, but, as spouses, they could only encourage their husbands to answer my questions, not give their own opinions. Indeed, the opinions about the necessity of a chief are often at least partially related to clan membership. Women can eventually talk about the topic in their own clans of origin.

For most commoners on Lakeba Island, as will be shown from the answers in my fieldwork, the highest values of the community, vanua (such as respect, rokovi, kinship relations, veiwekani, and loving each other, veilomani), are still linked to chieftainship, notwithstanding the fact that the structural opposition between the constituting parties (Sahlins 1981; 1985), chiefly clan and commoners, is still reflected the two sides' conflicting understandings of its relation to land. Therefore, the latter will be the first point of my demonstration. The second point will be the presentation of a deliberately created spatial confusion, followed by the description of three generations of title manipulations. These three points will also illustrate how and why the commoners' side was unable to influence or even to comment on the disruptions.

\section{Conflicting Understanding of the Relation to Land}

This was particularly evident when it came to land issues. There has been for a long time, a kind of misunderstanding about the "ownership" of the land between the "people of the land," itaukei, and the chiefs. As shown by many authors (France 1969; Pauwels 2015c; Ravuvu 1983; Walter 1978), commoners and noncommoners thought the land belonged to them. The confusion arises from the interpretation of the words "ownership," "land" and "soil". However, the terms during the installation ritual of the paramount chief in Lakeba Island, for instance, are very clear. The chief makers say they give the "entire responsibility," lewa taucoko, over the vanua to the chief, and they also give him the responsibility and authority over the "content of the land," lewe ni vanua, the people, the commoners. The chief, in his turn, declares to give back the "soil", qele, to the people so that they can cultivate for him (Pauwels 2015, 73). Thus, the word vanua does not designate the soil itself or any specific piece of land, at the core of discussions about land tenure. The chief is not responsible for the pieces of land (soil), but the people are, not as owners but as responsible users, farmers. As Fison $(1881,351)$ stipulated, "No man, whether chief or commoner, is the absolute owner of the soil ... Each generation does but hold ... under obligation to hand down the tribal estate undiminished for ever." What then is the vanua, often translated by "land" or "territory," for which the chief is responsible? The word is polysemic, but in its broadest meaning it refers not just to a place, but to a combination of place and time; it entails a spiritual dimension. As stated by Nabobo-Baba $(2003,7)$ "a person's vanua will mean his land [to live and to work on], genealogy, his history, his defined relationships with people [including his or her sacred chief], his duties and cultural obligations, his rights and his access to many things in life that are customarily defined." The members 
of a vanua are divided into a number of clans each with its function and place, in order to serve the chief. The chief, after a ritual installation, embodies the divine and in doing so relays forces that make things happen, "being effective," mana, especially during rituals. Through their various functions, clans are interdependent, and as chief makers, they also put their chief in a dependency. This balanced relationship is described by the word veiqaravi, "facing each other." According to Toren $(1990,87)$, these facts imply that chiefs and commoners ultimately "stand to each other as equals in an unambiguous exchange relation of balanced reciprocity." To a certain extent, I agree with this assertion, but this analysis does not take the encompassing part of the chief into account, that at a higher level, makes the vanua a totality, which gives the "content of the vanua" its sense of belonging, the fact that on that superior level "one of the terms, is everything to the other - and the converse is never the case" (Tcherkézoff 2009, 305). An installed chief is the only one who can carry the indestructible, inalienable title, the only one who can eat some particular food, touch some objects, and not be touched himself and who is the source of respect in the vanua (see below). These are all facts related to the gods and spirit-gods of the vanua, with whom he has a unique relationship. ${ }^{6}$

The fundamental divergence on the relation to the land of the territory (vanua and soil) between the chief and the chiefly clan and the commoners is at the centre of major complaining by the latter. We will see that the chiefly clan used and uses arguments and interpretations based on both the chief's secular and sacred sides, whereas the commoners saw and still today, to some degree, see no alternative to silent grumbling, because, for them, the sacredness of the chief makes public discussion impossible, whereas his secular side would not. However, over time and after more than a decade without a chief the "content of the vanua" considers the possibility of openly claiming land from the chiefly clan as well as of living without a chief. However, at least till today, this is only an admitted desire that is not acted on, precisely because the highest values of the vanua have not changed.

Even so, a lot has been written about chiefs in Fiji, especially concerning their transformations during and after colonisation by the British (Jolly 1992; Lawson 1996; Lawson and Hagan Lawson 2015; Pauwels 2015c, Rutz 1997). Indeed, the colonial administration created an institution in which a good many chiefs were reunited and which was to develop into the Great Council of Chiefs (GCC). The latter converted into mediators between them and their people in their territory or vanua where the Native Regulations Board, whose rules of course applied only to indigenous Fijians, had to be approved by the provincial councils of Fijian representatives, which could, incidentally, create their own resolutions and specific rules (Thomas 1990, 158-159). Chieftainship was at the core of the system, but the chiefs became representatives of the colonial administration in and outside of their vanua. As such, the regulations consisted of ordinances and obligations for the people (sanitation, road building, planting, construction, supplying visitors), but they did not mention reciprocal obligations from the chiefs. Thus the latter turned out to be two-headed: they remained sacred chiefs in a reciprocal relation with their vanua and they became secular chiefs in a nonreciprocal relation.

Later, at independence, they were the first politicians of the nation. Their leadership on a national level was not sacred, but sacred chiefs took the positions. For some of them, the power they acquired outside the vanua also gave them more power in the vanua and vice versa, in such a way that it was not always unmistakable where their authority originated. Rather than referring to these facts as transformations of the chiefs and the chiefly power, I prefer to consider them as the result of the addition of the secular quality to the chiefs' sacredness. Their sacredness remained the same and belonged to the vanua even if, quite often, they were building their secular power by using and abusing their sacred chiefs' prerogatives. These acts were called "neotraditionalism" but were the act of the chiefs themselves, not of the people, who, on the contrary, even today regret these attitudes and see them as usurpations of their relationship of balanced reciprocity, as well as situations in which the chiefs revealed a lack of respect for their sacredness. Moreover, the secular side of a chief should not be confused with his populist side, which belongs to the vanua sphere as one of the sides of his sacredness.

\section{Deliberately Created Spatial Confusion}

Writing about the chiefdom of Lau requires first considering that the word Lau embodies many meanings, as already mentioned by Steven Hooper (1996, 241), and that this polysemy leads to confusion even in the views of the current Lauans.

The easiest use of "Lau" to grasp is that of the province called Lau. It covers all of the chain of islands of the so-called Lau group as well as the islands of Moala, Matuka and Totoya (see Figure 1). This modern political unit is made up of the northern islands, which extend as far as Tuvuca, the southern islands from Ono-i-Lau in the far south as far north as Cicia, and the Moala islands (Moala, Matuku and Totoya). 


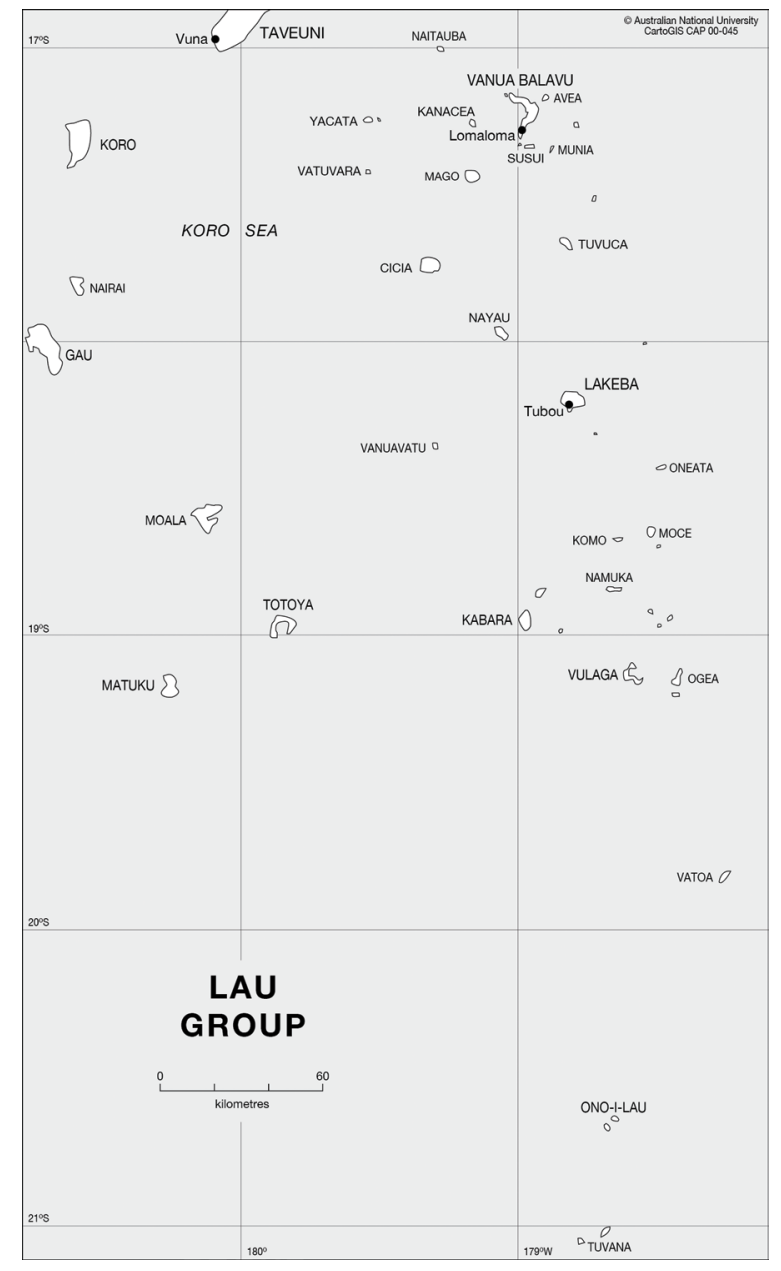

Figure 1: The Lau group.

Source: CartoGIS, College of Asia and the Pacific, The Australian National University.

Traditionally, the northern islands were under the overlordship of Cakaudrove and paid tribute to the Tui Cakau. The southern islands, which are the main area under scrutiny in this paper, constituted the traditional chiefdom of the Tui Nayau, whereas the Moala Islands, located west of the Lau Islands proper, were historically linked more closely with Bau Island and the Lomaiviti group than with Lau.

This, however, was before the influence of Ma'afu, ${ }^{7}$ son of one of the three Tongan high chiefs and potential successor. As a young man, having strong kinship relations with the Tui Nayau, he came to live in Lakeba. ${ }^{8}$ In the early 1850 s, he waged two wars commonly called "the wars of Christianity," valu ni lotu, which were actually wars of conversion, one in the Moala Islands and one in Vanua Balavu. His takeover with the tacit approval of the missionaries and his relative, the King of Tonga who made him governor of the Tongans in Fiji - left a profound mark on the archipelago. ${ }^{9}$ In Moala, after the war, new local chiefs recognised that their authorities derived from Lakeba, but also from Ma'afu and the Tongan powerbase on that island. In Vanua Balavu, the right of conquest also involved the effective sovereignty of Ma'afu. However, as Spurway (2015:134) writes,

These changes, while decisive, were not as clear-cut as they might appear in retrospect. When the British Commission of Enquiry, sent to investigate Cakobau's 1858 offer of cession, visited Lakeba in 1860, Tui Nayau informed the Commissioner, Colonel William Smythe, that the Moala group constituted an independent chiefdom, while Vanuabalavu owed its allegiance to Cakaudrove.

A new and enlarged Lauan chiefdom was nonetheless in the making.

In 1869, when the King of Tonga withdrew from Fijian affairs, ${ }^{10}$ the question arose of whether Ma'afu, as his governor, should leave Fiji. It was decided that the only way for him to remain was to create, with the complicity of the Lakeba chiefs, the European advisors and the missionaries, the new title of Tui Lau especially and only ${ }^{11}$ for him. In this way, he became the "Fijian chief" of a new chiefdom. ${ }^{12}$ The title of Tui Nayau, restricted to Lakeba and its zone of influence, became a secondary title, and its people had to pay tribute to Ma'afu. Vanua Balavu and Moala Islands remained under his direct rule.

Ma'afu's career did not stop there. Two years after his nomination as Tui Lau, he became viceroy in the short-lived, so-called "Cakobau government" before being given the office of Roko Tui Lau in the British administration, a position he held until his death in 1881 . One of his legacies was that the Lauan Province inherited the contours of his Lauan chiefdom. But was it really a chiefdom?

"No," was the very convincing answer of one of my informants from Lakeba: "How could it be a chiefdom where there were no traditional duties? There were no fishermen, no priests, no warriors, and so on." Indeed, there were only taxpayers! The tailor-made title of Tui Lau for Ma'afu made him a leader, a politician with ambition far beyond his territory, but not a sacred chief, neither in the Lakeba chiefdom nor in the Moala Islands, nor even outside Sawana, the Tongan village he founded in Vanua Balavu.

After Ma'afu's death, the Moala Islands and the two chiefdoms in Vanua Balavu turned back to their sacred chiefs, whom they probably never ceased to respect. But Vanua Balavu has not returned under Cakaudrove's sovereignty, even if the link is still remembered and even valued..$^{13}$ 
Sawana remained an exclusively Tongan village, with its language, its culture, its Tongan church and its links to Tonga, even if no Tui Lau had been installed for nearly six decades. The title was made for Ma'afu only and the British administration, after his death, repeatedly appointed a Roko Tui Lau, which is a purely administrative function without any link with the Tui Lau title but covering the same territory. In 1938, however, Ratu Sukuna, who had become an important figure in the colonial administration, was in need of a title to substantiate his role. How could the Fijians respect a leader with no title? He was installed as Tui Lau following a consultation between the yavusa ${ }^{14}$ Toga of Sawana and the endorsement of the then High Chief of Lakeba, the Tui Nayau Ratu Tevita Uluilakeba, who was also Sukuna's crosscousin and friend. He held the title until his death in 1958.

Many things are remarkable here. Not only was the Tui Lau title revived, as if it were a traditional and sacred title, which never dies but sometimes lacks a bearer. Moreover, the yavusa Toga was recognised as its owner and the Tui Nayau as its final approver. Most surprisingly (but maybe not for a made-up chiefdom), Ratu Sukuna, who was of Bauan descent but had no access to a chiefly title, won a Lauan (Tongan) title with the argument that he was Lauan through his mother, who was the former Tui Nayau's sister. Indeed, this relationship enabled him to register in the Vola ni Kawa Bula (Register of Native Land Owners) under his mother's subclan, ${ }^{15}$ Matailakeba.

For the colonial government, the stratagem was a success: it gave Ratu Sukuna the chiefly authority needed to impress the Fijian people, first as a member of the Legislative Council to represent the Fijian people, then as a district and provincial Commissioner, and, from 1940 on, as the great architect of the Native Land Trust Board. For the colonial government and for the Fijians, as a statesman, he became at that time the greatest chief perhaps one should say leader - in Fiji. His influence and indisputable authority in the recording of Fijian land tenure are well known and are still the source of many issues. Over time and with the declining power of the chiefs and the new approach of the actual government, to the detriment of the chiefly lines, his role became more and more openly debated.

Under his sovereignty as Tui Lau, the Lauan Province was again treated as if it was a single chiefdom, or a confederacy of chiefdoms, whose orchestrator was Ratu Sukuna, like his forbearer Ma'afu. He reinstated the Moala Islands into the Lau group to support traditional gift giving through provision of taro (Moala's crop) and other farm products to the Tui Nayau. ${ }^{16}$ In doing this, he touched a raw nerve for every Fijian when he appealed to his grandfather Mara Kapawai, who had strong links with the island through female lines. ${ }^{17}$ As a result, he saw himself provided with a big piece of land as a result of his Moala ancestry, which he accepted. Scarr $(1980,80)$ writes

he [Ratu Sukuna] went on registering land to mataqali who could show occupation at Cession - except where custom permitted transfer to an individual or another group. Ai covicovi ni draudrau ["the picking of leaves, vegetables"] was one case, that is to say land given as dowry to a woman of rank and her descendants; in virtue of this, the Moala people now gave Ratu Sukuna land in memory of the Moala Lady who was Ratu Mara Kapawai's grand-mother.

Interestingly, this land is known as Kovukovu, which is the name of a form of land transfer set up by Ratu Sukuna and the Land Commission in 1936 (Gatty 2009, 122) and which designates a land reserve assigned to outsiders (affines) for their own use, not to be leased to others. The assignment can be inherited even if it remains distinct from ownership. Kovukovu land quickly superseded land given, temporarily, as dowry to a woman of rank and her descendants in order "to be able to feed her children." It became one of the means for men (chiefs and chiefly clan members) with little land to acquire some, in full and in perpetuity.

On Vanua Balavu, the Native Land Enquiry started the very same year as Ratu Sukuna's installation as Tui Lau. A most important social reorganisation, in intimate connection with the official recording of land rights, was implemented by the administration of which Ratu Sukana was the brain as the commission's chairman (Walter 1974, 302; 1978, 100). He had to deal with the thorny problem of the so-called magimagi ${ }^{18}$ land. Indeed, Ma'afu had divided the fertile coastal flats in Vanua Balavu and Lakeba into plots that were distributed to the patrilines to satisfy his need to increase tax income and providing the Tongans, his warriors, with land. This was done in total disrespect for the original landowners. ${ }^{19}$ For decades after Ma'afu's death, the status of the landowners had been very confusing and a source of many conflicts. Before subdividing the people into new administrative clans, "landowning units according to the colonial government's wish," Ratu Sukunu decided, in the same way Ma'afu did before him, that, should a patriline die out, the land would then revert to the Tui Lau, that is to say to himself, who would then determine its disposal. ${ }^{20}$ As Walter explains,

The last clause caused considerable agitation and resentment in Mualevu, fed by the rumour that the newly created yavusa Tonga, which included 
all registered Tongans in the Lau Group, would be allotted the magimagi lands. The rumour was given strength when the Tongan community in Lomaloma disputed most of the magimagi lands it had knowledge of, so preventing many from being incorporated into clan proprietorship. Few of the magimagi disputes were settled at the Enquiry: the notification of a dispute was recorded, but the hearing of evidence and the giving of judgment were made pending to a later date. Sukuna qualified his ruling on magimagi in December 1939, and the following January the Enquiry was suspended because of the War. ${ }^{21}$

In the chiefdom of Lakeba, Ratu Sukuna was also active as native lands commissioner, and in 1939 he even appointed the Tui Nayau himself as his assessor. As everywhere in Fiji, the native land commissioner for each village had to draft his or her findings in a document, the content of which was binding and which was called Tukutuka Raraba, literally "the tales of origin," also translated as "tribal statements." For Tubou [the chiefly village of Lakeba], this document was scripted under the influence and scrutiny and probably by the pen of the two most powerful men of Lakeba and Lau. ${ }^{22}$ One of the remarkable facts for this village is the creation, to adapt to the colonial administration's will of uniformity, of a single yavusa in Tubou, named the yavusa Lakeba. This unites the chiefly clan Vuanirewa and four vanua or "land" clans and denies the pre-existence of the various yavusa of the "people of the land," lewe ni vanua. As we will see, for these yavusa this is still a painful thought. The new yavusa's name is (intentionally?) misleading at least, since strictly speaking it designates the whole island, but in reality it refers only to the inhabitants of Tubou. Nevertheless the content of the Tukutuku Raraba ni yavusa ko Lakeba, ${ }^{23}$ while focusing on the primordial role of the chiefly group, speaks also about some, but not all, of the other groups ${ }^{24}$ on the island. It insinuates that all of them have lived in two big settlements, Ulunikoro and/or Kedekede. It claims too that at one point, sometime at the very beginning of the nineteenth century, the inhabitants lived under the threat of a cannibal and asked the Vuanirewa people of Nayau to free them from him. The document does not mention the assistance or even the existence of groups who never lived in Ulunikoro or Kedekede, but who made it possible for the Vuanirewa to take over power. However, their reality is not consistently denied in the document because it is written there that "when the Sau of Kedekede was installed as chief, all the yavusa in Lakeba were present," implying that other yavusa existed as well elsewhere on Lakeba and that they each played an important role in the development of the new chiefdom.

The analysis of the Tukutuku Raraba deserves an article in itself, but concerning the very origin of the confusion between the Lakeba or Southern Lau chiefdom and the Lau chiefdom, the key paragraph is the one that claims that

The Tui Nayau can send a messenger to have his work done by ${ }^{25}$ the Ramasi from Nasaqalau, Tui Ra from Vakano and Yadrana, Tui Soso from Nukunuku, Tui Navuaira from Waciwaci, Tui Moala from Moala, Sau from Totoya, Tui Naro from Nayau, Tui Cicia, Tui Kabara, Ramasi from Moce, Tui Vulaga, Tui Oneata, Tui Ono, Sau from Mualevu, Ravunisa from Lomaloma and Daulakeba from Levuka.

Nasaqalau, Vakano, Yadrana, Nukunuku, Waciwaci and Levuka are the villages of Lakeba. Interestingly, the village of Waitabu is missing, and Tubou, the chiefly village, not being mentioned is also remarkable because its inhabitants perform a lot of essential "work" for the Tui Nayau. Cicia, Nayau, Kabara, Moce, Vulaga, Oneata and Ono are the names of the main islands, which were already under Lakeba's sovereignty before Ma'afu. Most surprisingly, the text claims that the chiefs of Mualevu, Lomaloma, Moala and Totoya were under the chief of Lakeba. This is a historical untruth that was written down in the presence and authority of the Tui Nayau and the Tui Lau while they swore on oath that whatever had been decided was binding! With regard to Moala, for example, Sahlins clearly states that, at least from a Moalan point of view, "the allegiance of Moala to Lau (as well as to God) was essentially created by Ma'afu's conquest of Moala. It was perpetuated after 1874 by the Government of the Colony which made Moala a District within Lau subordinate to the Government chief of the Province, Roko Tui Lau" (Sahlins 1962, 17). The consequences of Ma'afu's conquests, be it in Vanua Balavu or Moala, Totoya and Matuku, were religious and administrative; the then paramount chief of Southern Lau did not became theirs. We will see that these facts are still not wiped out of the memories of those concerned and that they lead to a lot of confusion, misunderstandings, dissension and maybe future conflicts.

\section{Three Generations of Title Manipulation}

If the legitimacy and the outlines of the Tui Lau title are more than debatable, what about the double title of the paramount chief of what we can now safely call the "Lakeba Chiefdom" (excluding the Moala Islands and the Vanua Balavu territory)? Nowadays, the entire title is supposed to be Tui Nayau kei ("and") Sau ni Vanua 
ko Lau. The Tui Nayau title as such is not problematic, and is recognised as being the title brought from Nayau Island to Lakeba during the second half of the eighteenth century, when the bearer of the title was made the paramount chief of Lakeba and its dependencies in Southern Lau. The title Sau ni Vanua ko Lau is more questionable. As far as I know (but research is ongoing), the first researcher to mention the Sau title in relation with the Tui Nayau was the anthropologist Maurice Hocart, who was the head of the first Lauan school in Tubou from 1909 till 1912. He wrote in his manuscript,

Ratu Finau also bears the title of Sau, a term which is often used to describe High Chieftainship in general. Ratu Finau is seldom alluded to under the title Tui Nayau, but always as Roko Sau, or simply $i$ Turaga, the chief. At the present time they often call him Roko, which is short for Roko Tui Lau [the a colonial administrative title for the head of the province]. ${ }^{26}$

And Hocart continued,

While the chief is only Roko Sau the first fruits of all kinds of food are brought to Lakeba from Nayau, such as taro, yams ... Roko Sau is not a great chief; Tui Nayau is. ${ }^{27}$

Hocart also gave a description of the installation ritual of the Sau, specifying that "the last installation ceremony was in the [eighteen] seventies," that is to say, during Ma'afu's and Eroni Loganimoce's reign and at the time of the Deed of Cession (1874). If Hocart is right and if the installation ritual as he describes it is a faithful oral testimony from one of his informants, then it is conceivable that the Sau title is an abbreviated reference to the already mentioned oldest title on the island, Sau of Kedekede, as in "The two Ramasi, that is Tui Tubou and Tui Nasangalau, together with Vakavanua, the chief of Cekena, Tui Soso, the chief of Nukunuku, install the Sau." ${ }^{28}$ Indeed, this description reveals that the men involved in the installation were the same as those who were the most important dignitaries before the arrival of the Vuanirewa. Cekena was even the yavusa or clan of the former Sau of Kedekede.

However, in the Tukutuku Raraba, three decades after Hocart's testimony, the title underwent a spatial expansion: "The preparation of the installation of the chief was done all over Lakeba, then he was installed as Sau of Lakeba." Since then, the title has experienced a new transformation. What had happened?

In 1963, Ratu Mara, Ratu Sukuna's grandnephew, became Tui Lau, "reputedly chosen after his father approached the yavusa Toga" [in Sawana, Vanua Balavu] (Scarr 2008, 119). His father still being alive, it was the only title available since Ratu Sukuna's death in 1958. His mother being a member of the yavusa Toga, the bestowal did not involve any problems. For Ratu Mara, who was rapidly becoming an important politician, a chiefly title gave him weight not only to represent the Fijian people but also to discuss delicate issues such as racial integration as a goal for the government. Note that this was the third time the Tui Lau title was assigned and the third time it was a gateway to national politics for the carrier. Thus, Ratu Mara became a secular chief, anticipating the inheritance of his sacred chief's titles.

Indeed, after his father, Ratu Tevita Uluilakeba, died in 1966, Ratu Mara took over his titles of Tui Nayau and Sau of Lakeba in 1969. For the first time, one single man held the three titles. However, Ratu Mara did not become Sau of Lakeba but Sau of the Land of Lau, Sau ni Vanua ko Lau. It seems that to strengthen his secular title, his sacred title had to spatially coincide with the extent of his sacred title. In fact, the spatial difference between Lakeba and Lau was already bridged in the Tutuku Raraba when it was written that the work of the Tui Nayau was done by all the yavusa of the territory covered by the Lauan Province. However, now the chiefdom of Southern Lau became the chiefdom of Lau by name, with a territory equivalent to that of the Province of Lau. A young friend from the chiefly clan told me that, during a meeting with the chiefs of the islands of the province of Lau, Ratu Mara had asked for their approval, ${ }^{29}$ which, if true, shows that he consciously created (extended) the title. Publicly, nobody, except Totoya ${ }^{30}$ seems to have taken offence at the shift from Lakeba to Lau in the Sau title.

As far as I know, there are no descriptions of the installation ritual of the Sau other than the one in the Tukutuku Raraba and Ratu Mara's installation. Nearly 100 years separate those two rituals. Speaking about the preparation of his installations, Ratu Mara writes in his memoirs, "I might add that the nature and order of the ceremonies had involved long talks with the elders over the yaqona bowl, far into the night!" (Mara 1997, 95). Scarr $(2008,160)$ writes, "At his installation as Tui Nayau in Mid 1969 by ritual based on research and recovered memory ${ }^{31}$ he was ...." The result was a reversal in the order of making him a chief as Tui Nayau and as Sau! Where Hocart clearly states that the title bearer has to be Sau before being installed as Tui Nayau ("Roko Sau is not a great chief; Tui Nayau is"), approximately two years later, Ratu Mara became Tui Nayau before being installed as Sau ni Vanua ko Lau the next day. My hypothesis is that the reversal was no coincidence. The climax of the two rituals took place in Tubou, the chiefly village; the role of the people in Nayau in choosing the 
next Tui Nayau was belittled; and now some people even believe that the title of Tui Nayau is smaller than that of the Sau and that the next Sau has no reason to worry about "so minor a title." No doubt these thoughts emanate from people who believe that the title Sau ni Vanua ko Lau rightfully includes the territory of the whole of the Lau Province.

\section{A Chief or Not a Chief: A Buridan Paradox}

Ratu Mara died in 2004, and since then no new Sau or Tui Nayau has been appointed. The Vuanirewa unwritten rules on succession tend to respect the following three principles: (1) to pass from elder to younger brother until that generation is extinct, then taking the next generation in the same order, (2) to alternate between the two noble clans, or subclans ${ }^{32}$ Matailakeba and Vatuwaqa, and (3) to recognise the superior nobility of the senior branch in the clan or subclan. In Tubou, it is understood that the people from Nayau Island observe the same rules for the Tui Nayau, and thus do not question the choice of the Vuanirewa even if some men in Nayau claim that they should be consulted, if not even be responsible for the choice. These are the rules. However, since Ratu Finau's father, each of the successive paramount chiefs has belonged to the Matailakeba subclan, because, according to the official version, the title bearers named their successors, as is usual in many parts of Fiji, and it was impossible to go against their will even if the alternation between the two noble clans was not respected..$^{33}$ No doubt this was the case for Ratu Mara, who was prepared for his role in the nation by Ratu Sukunu with the consent of his father. For this destiny, it was considered essential to hold an important sacred title.

It is the tradition that for two years after the death of a chief no successor is sought, because the chiefly mana is believed to be around still. Once there is agreement on his replacement, it usually takes another year to prepare the installation. ${ }^{34}$ In 2006 , however, a military coup took place in Fiji, and one of the first things the coup leader did was to suspend and later cancel the Great Council of Chiefs. Hence, the influence of the aristocracy had been eroded at the national level and in some places at the local level as well. At that time, for some people in Lakeba who did not want to upset the coup government, it became no longer important to look for a new chief. Others, such as the delegates from Nayau Island, approached the eldest son of Ratu Mara as soon as March 2005. ${ }^{35}$ For years, his supporters were more numerous than those in favour of the brothers of Ratu Mara. The candidacy of Ratu Mara's other son, Roko Uluilakeba, was also on the agenda for some of his followers.$^{36}$ Over the years, the reasons given to explain the absence of a nomination varied, but revealing some of them here is not within my competence and would betray the confidence of my informants.

However, as mentioned before, in late 2015, I had the opportunity to question some men of the villages ${ }^{37}$ in Lakeba about the relevance of installing a chief after a decade of vacancy. Their answers, of which I give excerpts here, are selected to be representative. They all gave ascendancy to one side of the sacred chief, populist or kingly. Nevertheless, their first and very spontaneous answers to my inquiry as to how they felt about the absence of a chief were complaints about the burden of having a sacred chief serve without counterpart, without balanced reciprocity. One of the elders immediately said, "Part of me is relaxed, the other part is missing something." And another added, "We feel good right now, less burden. The island right now is making a lot of money. The paramount chief is a hindrance to the personal business. Now people take their chance. It is not too late to choose a chief, but not a Great Council of Chiefs, chiefs should sit in the village." Obviously Ratu Mara as paramount chief had been experienced as obstructing personal initiative, a blame that often returned in even harsher terms as time went by. In some villages, people insisted that the beneficiaries of development were the Vuanirewa people, the chiefly clan, or Ratu Mara himself, sometimes to the detriment of landowners who had been dispossessed. In one village people mentioned, emphasising the point made, that they were even deprived of the fame of the cricket team "which was always called the Tubou, name of the chiefly village, team even when the players were from the villages of Yadrana, Vakano and Waitabu." The opposition between "us" and "him" (Ratu Mara) or "them" (the Vuanirewa clan members) also exists inside Tubou, whose clans Ratu Sukuna forcefully merged into the yavusa Lakeba.

Villagers also remember what they consider the theft of land for the benefit of the Vuanirewa clan during Ratu Sukuna's work at the Lands Commission. ${ }^{38}$ Ratu Mara also asked for land to establish his development projects, implying lease money, which they consider not to have been collected. These facts are a perfect illustration of the confusion between land and soil and the different points of view of the chiefs and the commoners about whom the land belongs to. Ratu Mara, as a sacred chief, had the entire responsibility over this land. The people of the land's perspective considers that Ratu Mara, as a secular chief, wanted to bring development (airstrip, national prison, vocational school, hospital, sawmill, etc.) to his home island. Therefore, he needed land that they had to relinquish living on or to cultivating. Every project paid lease money, which both parties considered to 
be theirs. The problem would have been different if Ratu Mara as a sacred chief had asked them to give up land for a vanua cause such as the enlargement of the central sacred green. No lease money would have been involved either. The vanua never considered the development projects of Ratu Mara as part of the gifts in the mutual exchange relation between sacred chief and vanua.

The last paramount chief was of course at the opposite from the current government's all-out development projects, which are established indifferently to landowners' identity and which indeed seem to increase some of the islanders' income. In one village it was affirmed that a sitting chief would not make any difference "as development (community hall, pearl farming, sea cucumber, seaweed projects, and so on) comes, through the Provincial Office, from the government."

This is not the place to evaluate Ratu Sukuna's or Ratu Mara's deeds, but it becomes clear that they failed to explain or convince the people of their right to do what they did. As for Ratu Mara, it looks as if he misunderstood the words of the installation ritual explaining that he receives "the responsibility over the land, vanua, but that he has to give back the soil to the people so that they can serve him." "Responsibility" does not mean "power" but the obligation to take care of the land and the people. The confusion drives people to say, "This way (without Tui Nayau) is better, it is a burden with no benefit. Before the chief gave back, now it is a one-way traffic. You only give!" Indeed, they expressed a wish for a sitting chief whom one could visit and explain concerns and be listened to returned ceaselessly. In each case, Ratu Mara was in this context compared with his father, who is said to have been a very good Tui Nayau, "loving his people, being kind, understanding, giving what was asked for, approachable ..." or not being greedy as "we brought him food, he returned favor. We bring less but the chief gives more. He was served with all their hearts!" He was in every term conforming to the populist side of a chief, whereas, according to all the testimonies, Ratu Mara was not. What about his kingly side?

When I asked my first speaker quoted at the beginning of this excerpt was the other part of him that was missing was, he answered: "Traditional leadership has to be maintained. Hierarchy has to be there: Chief, Matanivanua, elders ..." The kingly side of chieftainship surfaced, as it did in another village when one elder said, "There is a loss of value, leadership has deteriorated, young people do not listen, the chiefly system is disrespected. The Tui Nayau should be installed to restore these values of respect. 'I am this, I am that' of the young shoots is very annoying and dangerous. We gain nothing with a chief sitting, it is a burden, but the respect of old people, and so on, has to be restored." Everywhere in Fiji the value of respect is inextricably linked to the chiefly system. It looks as if a child listens to his father, the father listens to the chief of his clan, who listens to the chief of the village, who listens to the high chief, and so on. However, from the Fijian viewpoint, it is the other way round; it is the respect of the vanua toward the chief that is the model. It is because their parents respect the chief that children respect their parents. The absence of the chief, according to nearly all my interlocutors, takes its toll in every relation of deference.

Ratu Mara established the kingly side of chieftaincy himself by being the initiator of his two installation rituals and especially the one as Sau ni Vanua ko Lau, for which he organised the reinvention and the new name. He still has the reputation of being very distant, unapproachable, enjoying submissiveness and respect. Of course, his national destiny as chief minister, prime minister and then president made it difficult to assess who exactly was revered, the chief or the politician.

Villagers are still very much aware of the sacredness of the title of chief and the mana it represents. One man said that "The Tui Nayau, the title and the mana, is always there, but we need somebody to sit (and to carry it)," and another man explained that "There should be somebody sitting, without somebody sitting there is disorder." It is also not uncommon to hear phenomena such as cyclones, bad harvests and profusion of kava drinkers attributed to the long vacancy of the chiefly seat. The people of one village even insisted on their distress at not being able to perform their traditional roles toward the chief, saying they felt useless. Their opinion was that the function holders, masi, ${ }^{39}$ of the chiefdom are those who should ask the man chosen to endorse the title "because they are the ones that will serve him, not the Vuanirewa." They explain the difficulty of Ratu Finau, Ratu Mara's son, accepting "to sit" by this formal error. According to this point of view, it is as if the ritual had to repeat oral history as written down in the Tukutuku Raraba, where we read that it was the masi, represented by the Tui Tubou, who went to Nayau to ask the Vuanirewa clan to become chief in Lakeba. Some Vuanirewa members now pretend that they do not need the people of Nayau to install the chief; they even go as far as pretending to make him chief without the Tui Tubou. One can only wonder what the title will look like and who will respect it if this happens.

For almost every villager in Lakeba the title Tui Lau, the secular title, is indisputably linked to the person of the Sau or the Tui Nayau. Most of them were very amazed to learn or to be reminded that Ratu Mara was Tui Lau six years before being installed as Tui Nayau 
and Sau and that at that time his father was still alive. They also feel uncomfortable when told that, for some people, it is the yavusa Tonga in Sawana who is supposed to choose the titleholder, with or without the consent of the members of the Vuanirewa clan. In Sawana in 2015, I learned that not one but three candidates are under discussion and that the yavusa members were not planning to wait much longer than $2017^{40}$ to install a Tui Lau, be he Tui Nayau or not. This news caused very lively reactions in Lakeba in terms I cannot disclose here.

Much to my surprise, this incident revealed another important title in the Lauan context I hinted at already: ${ }^{41}$ the Roko Sau of Totoya. For the inhabitants of one village, he, and not the Tui Lau or the Sau ni Vanua ko Lau, is the real high chief of the whole of Lau. According to them, the history of the Vuanirewa started later than the history of the Roko Sau of Totoya from which they descend. They blame the Vuanirewa for hoping that this precedence will never be revealed. This village's version of the history, which I am not allowed to reveal further, is assented to by two other villages, equally frustrated by the version of the Tukutuku Raraba of the yavusa Lakeba, which does not give them their justifiable share in history. For them, the title of Tui Lau cannot compete with the title of Roko Sau of Totoya "because the Tui Lau has no masi (no function bearers), it is a political title." The elders from another village wished that at least one sacred title should include the whole of the islands of the Lau Province. They choose the Sau ni Vanua ko Lau title to do so, however, because "if the Tui Nayau does not have this title then there will be Sau titles that he will not control, such as in Totoya and Vanua Balavu." This opinion clearly puts a Sau title above a Tui title and expresses the need to unify the islands of the Lau Province under a sacred title.

For the men of one village, there was no problem, as "the Sau ni Vanua ko Lau is entitled with everything in the province," thus mixing chieftaincy and administrative territory. A masi of the same village did not see any problem, since for him the three titles gave rights to the whole of the Lauan Province. He switched with staggering ease from chiefdom to province, to provincial council, to masi, and so on. One must concede that the representatives of chiefly and governmental institutions are substantially the same in the territory of the Lau Province. A situation many admit this while adding that it dates from Sukuna's time and that they regret "he revived the Tui Lau title where it should have died with Ma'afu." We can therefore definitely claim that the manipulations of the past created a twisted situation in Lakeba and in the Lau Province. To be discreet and to be cautious about unverifiable data, I only reveal a small part of the grumbling of the vanua, but this grumbling disclosed various levels of conflicting understanding between the chief, including the chiefly clan, and the people of the land or commoners. Thus, the two-headed chief, secular and sacred, represented by one single person is something the people of Lakeba do not want any more, first because, during his functions outside the vanua, the sacredness of the chief is not respected; second because when the secular and the sacred chief is the same individual he could, following the example of the late paramount chief, introduce secular gifts into the island, expecting return gifts that belong to the sacred vanua sphere. These ideas were indirectly summarised by an elder: "He should create his wealth before he becomes a chief, not during his chieftainship because then he will cheat his people. The people will have to make his yam garden, cut his copra and then he sells it, and so on. There is a conflict of interest." These words confirm the different expectations between, on one hand, the commoners who "serve" the sacred chief and expect the chief to serve them in return and, on the other, the commoners who cut copra for the chief, who allows himself to sell it instead of serving his people, considering probably that he has already served them by building the hospital.

When the vanua members express themselves about the necessity to have a sacred chief, they invariably speak about the value of respect, which they consider to be a constituent part of hierarchy in the vanua and which is also the condition for preventing disorder, the kind that appears when the members of the chiefly clan and the vanua do not know their place or function anymore. The mana, the "efficacy" of the sacred chief, originating in his relationship with the ancestor spirits of the vanua, constitutes the other part. People expect the mana to flow from the chief to the vanua, because respect circulates in the opposite direction. This directed circulation dictates respectful behaviour, from children toward their parents, from the younger toward elders, from younger siblings toward the elder, and so on, and enables the flow of mana in the opposite direction.

All my informants expressed ideas indicating that the chief should be two-sided, populist and kingly. He has to be approachable, work in the interest of the people - eventually teaching them how to become successful: be self-sufficient, have an honourable life but also be respected, and thus socially distant and the passive embodiment of responsibility. They expect their chief to take care of them in a rather populist way and in (re)turn they are ready to respect him as a "king," but with the admitted ulterior motive that this will produce, through example, order in the relationships between the members of the vanua. This looks like a rather 
opportunist and functionalist reasoning that does not take into account what happens in the installation ritual, when the masi "make a chief" and when this chief becomes the embodiment of the ancestral gods. Only then will he show his qualities. Who knows today how the vanua will respond?

\section{Simonne Pauwels, Aix-Marseille Université, CNRS, EHESS, CREDO, UMR 7308, Marseille, France; Labex Corail.Email: simonne@pacific-credo.fr.}

\section{Notes}

1 Lau Ratu Sukuna, DC Lau Monthly Diaries, 1932-1939, Fiji Archives, F15: 5, parts 1-6; Tukutuku Raraba ni Yavusa ko Lakeba, typescript, 15 pp., 1939, Native Land Trust Board.

2 Mara (1997); Reid (1990) Scarr (1980; 2008); Sukuna (1983).

3 Hooper (1996); Sahlins (1962); Thompson (1938; 1940(; Walter (1974; 1978); Young (2001).

4 Apart from two brief interruptions in 1977 and 1987 (Lal 2010, Mara 1997).

5 "Commoner" here means every person who does not belong to the chiefly group, regardless of the traditional function or place of his or her group in the chiefdom (priest, warrior, farmer, fishermen, navigator, etc.).

6 We are conscious that the discourse about this relationship changed a lot with the introduction of Christianity, but the behaviour toward the chief stayed appreciably the same. Moreover, in Fiji, the concept of mana, from a stative verb, "be successful" (Keesing 1984) evolved through the decades into a noun, today often translated by "blessings" and thought to be conveyed by the Christian God and the chief as testimony to the right behaviour of the people.

7 For further historical details and a close analysis of the issues through the life of the Tongan chief Ma'afu, see the excellent work of Spurway 2015.

8 According to the Tongan National Archives (DouaireMarsaudon 1998; Kaeppler 1978) and Lakeba's oral history, Tongans regularly visited the Southern Lau Islands, at least since the seventeenth century, not only to build their boats and to collect the red feathers of the kula bird (collared lory, Phigys solitarius) but also to find husbands for the kings' eldest sisters as well as warriors. Lauan chiefs received wives in exchange and highly value(d) the resulting kinship ties.

9 Lakeba is the island where the first missionaries arrived in Fiji. They came through Tonga, which was Christianised earlier. It is difficult to decide if Ma'afu took advantage of religion to wage a war of conquest or not.

10 Since 1835, Tupou I played a crucial role in the introduction of missionaries into Fiji. He also assisted a Fijian paramount chief in a war in 1855 because they had become brothers in religion. But it seems that in 1869 he lost interest in having a Tongan colony in Fiji, as he was not free of opposition at home (see Campbell 1990).

11 See Scarr 2008, 18.

12 See Pauwels 2015c.

13 Did they feel abandoned or did they remember the selling of nearby islands such as Mago, Katafaga and Kanacea by their overlord? Further research is needed to answer these questions.

14 In the colonial administration's distribution of people, yavusa, "tribe," is the most inclusive social unit, including the "clans" and the tokatoka "sub-clans." The definition of these social units is still subject to local variations, which makes their translation risky.

15 Some consider Matailakeba as a clan, which shows that the manipulations of social units to simplify colonial administration all over Fiji are still not assimilated.

16 Mixing secular chiefs' and sacred chiefs' prerogatives, as we know Matuku, Totoya and Moala considered having their own sacred chief.

17 See also Reid (1990, 32) and Sahlins (1962, 337).

18 France explained: "Land was apportioned by allotments to all taxpayers in the group, by measuring out a certain frontage along the beach with sinnet rope. The allotments were known as magimagi (sinnet); though they were ideally 100 fathoms in width, they seem to have varied in size with the rank of the recipient ... visiting Tongan warriors who decided to stay in Lau were appointed areas as well as the long-established Tongan residents" (France 1969, 85). The land given was supposed to provide them with the means to harvest copra and thus to pay taxes.

19 France $(1969,85)$ wrote, "the Lau islanders seem to have received the system with some enthusiasm." The latter was not lasting, to judge by the huge number of cases alluded to by Ratu Sukuna in his diary on April 21, 1938: "more NLC disputes here (Lomaloma) than in the Provinces of Bua and Macuata added together."

20 See Young $(2001,365)$.

21 Walter adds that "it was left to Thomson's Commission in 1965 to give judgment on the majority of the magimagi disputes. The reason the Mualevu District Tongans did not register with 'Fijian' clans in 1938 was the promise of magimagi lands held out to them by the Tongan leader in Lomaloma." One may wonder if it is coincidental that the Thompson Commission worked in Lomaloma two years after Ratu Mara's installation as Tui Lau (see further).

22 The paramount chief or Tui Nayau and Ratu Sukuna, the Tui Lau.

23 To my knowledge, only a few copies circulate in the island, but its content is the subject of many discussions.

24 Perhaps "yavusa."

25 "E dau vakatadumata ka lala na Tui Nayau vei ...” (p. 15).

26 Hocart, Arthur Maurice. The Windward Islands of Fiji (1909-12). Manuscript, 653, 87.

27 Hocart, 88.

28 Hocart, 87.

29 What about the people? And who would dare to refuse this to a paramount chief and chief minister?

30 An informant from Totoya told me that the boat that came to pick them up to attend the installation had to wait three days because they disagreed on the title of Sau ko Lau. He declared that "The only Sau is in Totoya." In his mind that title is the highest. Unfortunately, space is lacking to expand on the historical link between the Roko Sau title of Totoya and the Tui Nayau title.

31 My italics.

32 Some people call them mataqali, others tokatoka. 
33 And as written in the Tukutuku Raraba, " $E$ dau buli na Sau se Tui Nayau e nai Tokatoka ko Matailakeba kei Vatuwaqa" (13).

34 That is the time for the growing of yams, the tabu on reef fishing, the manufacture of artifacts, and so on.

35 Fiji Times, 18 March 2005.

36 For a number of reasons he fell into disgrace with the coup government, which he had contributed to installing. In May 2011 he fled to Tonga, where he became a citizen.

37 Of course I am aware that the discourse of a few men cannot replace the point of view of all the villagers. But the examples will, at least, give an idea of their variety and their areas of congruence.

38 Pauwels (2018); Young (2001).

39 The function holders are called the masi in reference to the bark cloth made of the skin of the mulberry tree, which they are supposed to wear and which is the symbol of the land, the vanua, that they represent (see also Hulkenberg, 2016).

40 In the end, this was not done, but probably the destruction of the island by the cyclone Winston in February 2016 is not unrelated to the fact.

41 See note 31 .

\section{References}

Campbell, Ian. 1990. "The Alleged Imperialism of George Tupou I." The Journal of Pacific History 25(2): 159-175. https://doi.org/10.1080/00223349008572633

Douaire-Marsaudon, Françoise. 1998. Les premiers fruits. Parenté, identité sexuelle et pouvoirs en Polynésie occidentale (Tonga, Wallis et Futuna). Paris: CNRS Editions, Editions de la Maison des Sciences de l'Homme.

Fison, Lorimer. 1881. "Land Tenure in Fiji." The Journal of the Anthropological Institute of Great Britain and Ireland 10: 332-352. https://doi.org/10.2307/2841531

France, Peter. 1969. The Charter of the Land. Custom and Colonization in Fiji. Melbourne: Oxford University Press.

Gatty, Ronald. 2009. Fijian-English Dictionary with Notes on Fijian Culture and Natural History. Suva: Ronald Gatty.

Hooper, Steven. 1996. "Who Are the Chiefs? Chiefship in Lau, Eastern Fiji." In Leadership and Change in the Western Pacific, edited by R. Feinberg, R. Firth and K. WatsonGegeo, 239-271. London: Athlone Press.

Howard, Anthony. 1985. "History, Myth and Polynesian Chieftainship: The Case of Rotuman Kings." In Transformations of Polynesian Culture, edited by A. Hooper and J. Huntsman, 39-77. Auckland: Polynesian Society.

Hulkenberg, Jara. 2016. "Masi: House and Cloth of the Vanua.” Journal of Material Culture 21(2): 187-204. https://doi.org/10.1177/1359183515610136

Jolly, Margaret. 1992. "Custom and the Way of the Land: Past and Present in Vanuatu and Fiji." Oceania 62: 330-354. https://doi.org/10.1002/j.1834-4461.1992.tb00361.x

Kaeppler, Adrienne L. 1978. "Exchange Patterns in Goods and Spouses: Fiji, Tonga and Samoa." Mankind 11: 246452. https://doi.org/10.1111/j.1835-9310.1978.tb00655.x

Keesing, Roger M. 1984. "Rethinking 'Mana.” Journal of Anthropological Research 40(1): 137-156. https://doi. org/10.1086/jar.40.1.3629696
Lal, Brij V. 2010. In the Eye of the Storm. Jai Ram Reddy and the Politics of Postcolonial Fiji. Canberra: ANU E Press.

Lawson, Stephanie. 1996. Tradition versus Democracy in the South Pacific: Fiji, Tonga and Western Samoa. Cambridge: Cambridge University Press.

Lawson, Stephanie, and Elizabeth Hagan Lawson. 2015. "Chiefly Leadership in Fiji: Past, Present and Future." SSGM Discussion Paper 2015/5, pp. 1-17. Australian National University.

Mara, Kamisese, Ratu. 1997. The Pacific Way: A Memoir. Honolulu: University of Hawaii Press.

Marcus, George. 1989. "Chieftainship". In Developments in Polynesian Ethnology, edited by A. Howard and R. Borofsky, 175-209. Honolulu: University of Hawaii Press.

Nabobo-Baba, Unaisi. 2003. "The World in the Pacific and the Pacific in the World: Re-Examining Development Education." The Development Education Journal 9(2): 6-8.

Pauwels, Simonne. 2015a. "The Vasu Position and the Sister's Mana. The Case of Lau (Fiji)." In Living Kinship in the Pacific, edited by C. Toren and S. Pauwels, 143-165. NewYork/Oxford: Berghahn Books.

_ 2015b. "Soeurs et frères dans les îles Lau (Fidji): La relation entre village et ville." Anthropologica 57(2): 583-600.

(ed.). 2015c. "Chefferies fidjiennes d'hier et d'aujourd'hui." In "Nouveaux regards sur les chefferies fidjiennes.” Journal de la Société des Océanistes 141: 189-198. Available at https://journals.openedition.org/jso/7331\#xd_ co_f=ZTZmMDBlZDItZDdiZi00NTRiLWE4NjgtYjYxMžhlOTM5ZDI1 .

- 2018. "'Veiwekani, c'est bien plus que la politique': Etre ou ne pas être chef dans l'île de Lakeba à Fidji." In Médiations politiques en Mélanésie contemporaine, edited by P. Lindenmann, L. Doussett, and E. Nolet, 63-90. Marseille: Pacific-Credo Publications.

Ravuvu, Asesela. 1983. Vaka I Taukei: The Fijian Way of Life. Suva, Fiji: Institute of Pacific Studies at the University of the South Pacific.

Reid, Anthony. 1990. Tovata I \& II. Suva, Fiji: Fiji Museum.

Rutz, Henry. 1997. "Occupying the Headwaters of Tradition: Rhetorical Strategies of Nation Making in Fiji." In Nation Making: Emergent Identities in Postcolonial Melanesia, edited by R. Foster, 71-93. Ann Arbor: University of Michigan Press.

Sahlins, Marshall. 1962. Moala: Culture and Nature on a Fijian Island. Ann Arbor: The University of Michigan Press.

_. 1981. "The Stranger-King: Or Dumézil among the Fijians.” The Journal of Pacific History 16(3): 107-132.

- 1985. Islands of History. London and New York: Tavistock Publications.

Scarr, Deryck. 1980. Ratu Sukuna, Soldier, Statesman, Man of Two Worlds. London and Basingstoke: Macmillan.

—. 2008. Tuimacilai. Adelaide: Crawford House.

Spurway, John. 2015. Ma'afu, Prince of Tonga, Chief of Fiji. The Life and Times of Fiji's first Tui Lau. Canberra: Australian National University Press.

Sukuna, Lala, Ratu. 1983. Fiji: The Three Legged Stool. Selected Writings of Ratu Sir Lala Sukuna, edited by Deryck Scarr. London and Basingstoke: Macmillan. 
Tcherkézoff, Serge. 2009. "Hierarchy Is Not Inequality - In Polynesia for Instance." In Hierarchy: Persistence and Transformation in Social Forms, edited by K.M. Rio and O.H. Smedal, 299-330. New York and Oxford: Berghahn Books.

Thomas, Nicholas. 1990. "Sanitation and Seeing: The Creation of State Power in Early Colonial Fiji." Comparative Studies in Society and History 32(1): 149-170. https://doi. org/10.1017/S0010417500016364

Thompson, Laura. 1938. "The Culture History of the Lau Islands, Fiji." American Anthropologist 40: 181-97. https://doi.org/10.1525/aa.1938.40.2.02a00010 - 1940. "Southern Lau, Fiji: An Ethnography." Bishop Museum, Bulletin 162, Honolulu.
Toren, Christina. 1990. Making Sense of Hierarchy: Cognition as Social Process. London School of Economics Monographs on Social Anthropology, 61. London: Athlone Press.

Walter, Michael H.B. 1974. "Succession in East Fiji: Institutional Disjunction as a Source of Political Dynamism in an Ascription-Oriented Society." Oceania 44(4): 301-322. . 1978. "The Conflict of the Traditional and the Traditionalised: An Analysis of Fijian Land Tenure." The Journal of the Polynesian Society. 87(2): 89-108.

Young, Raymond. 2001. "A Land with a Tangled Soul: Lakeban Traditions and the Native Lands Commission." The Journal of the Polynesian Society 110(4): 347-376. 